\title{
ZWINGER, L. (2015). Telling in Henry James: The Web of Experience and the Forms of Reality. New York: Bloomsbury, 140 pp. ISBN: 978-1-5013-0898-7.
}

A century after his death, Henry James seems more alive than ever. As if he had become the protagonist of one of his horror stories, he returns to haunt us in diverse shapes: as the protagonist of successful biofictions, as a source for costume dramas, and as a challenge for translators and for scholars from all around the globe. ${ }^{1}$ But, as it is the case with his stories, this haunting is one we do not cease to enjoy. In his collection of essays The Year of Henry James: the Story of a Novel, novelist and critic David Lodge, as one of those enthralled by Henry James's legacy, explains that millennial fascination with his figure and works has its roots in "two fairly recent developments in the academic study of literature [...]: feminism and [...] Queer Theory" (Lodge 2007: 6), which have found in his characters and his personal life an object of study.

Leaving speculation about James's personal life aside, Lodge's statement demonstrates that James's prose, which was complex and turned particularly dense towards the end of his life, has been subject to constant re-assessment over the last sixty years (Lodge 2007: 5) through the prism of almost any existing theoretical framework. Lynda Zwinger is aware of this situation and cleverly avoids defining her latest work Telling in Henry James: The web of experience and the forms of reality (2015) as a truly original - hence impossible - reading of the Master's production. Rather, as she explains in the introduction, it presents a collage of many disciplines and approaches that can be applied to James, for she believes that James's prose is too rich to be addressed from the limitations of one single perspective. Thus, Zwinger's study stems from

pre- and post-structuralist phenomenology and formalism, Lacanian and postsecond wave feminism, psychoanalytic literary theory, and the burgeoning and polymorphously directional fields loosely gathered under the rubric "queer theory" (Zwinger 2015: 1-2).

alongside James’s own ideas about the nature of telling manifested in his essays.

1. When I mention James as "a challenge for translators" I particularly bear in mind the recent translation of James's The Turn of the Screw entitled La vuelta del torno that has been translated by Alejandra Devoto, Jackie DeMartino, and Carlos Manzano (Libros del Asteroide: 2015) and defies traditional translations of this work while trying to reproduce the experience of reading James's story in its original language. 
With this varied background, Zwinger embarks on the analysis of a set of texts that summarise his career, namely, his most influential and famous ghost story, "The Turn of the Screw" (1898), his early experimental novel The Europeans (1878), a short tale from the middle part of his career, "The Pupil" (1891), a novel from his last phase, The Golden Bowl (1904), and a tale called "The Jolly Corner" (1908), which she thinks embodies everything James thought the art of fiction should encompass (2). Thus, Zwinger's book offers an eclectic view of Jamesian prose while experimenting with the structure and form of the essays as if trying to mirror her main thesis.

Different in themes, quality and date of writing - perhaps because it is based on earlier pieces of criticism she had published in other venues -, no thread seems to unite the pieces of writing analysed at first sight. However, Zwinger links them with a metaphorical one she found in James's essay “The Art of Fiction” (1884): that fiction can be turned into an art comparable to that of painting, which does not only tell, but is able to capture experience. Zwinger's thesis is that in his quest to achieve so, James abandoned his status as a narrator to become a "spinner of the web of fiction in which the forms of reality are caught" (Zwinger, 2015: 6).

Perhaps in an attempt to emphasise the message, in Telling in Henry James the argument is not built chronologically and there is no linear link between one chapter and the following. Instead, it parallels the structure of the web, in which different agents are interconnected, Henry James and his own concept of fiction placed at the centre while his primary texts and contemporary literary theory orbit around them.

The first chapter of the book draws on the above-mentioned passage from "The Art of Fiction" in order to introduce the concepts of "reality", "experience" and "art" on which the whole metaphor of the spider web is sustained. Roughly speaking, the problem addressing James is that his spider web is built often on what cannot be seen, and the taxonomy traditionally used in criticism describes "what can be seen" (13). Thus, Zwinger is convinced that close reading is the tool that we may use to appreciate what James leaves out of the text but we can feel in it (14) - that is, experience - revealing that telling is more complex than just language (15-16). Through close reading, too, she can find in James's fiction words that seem "out of place" (22) but that she believes have the purpose of building upon the reader's experience. Consequently, the subsequent chapters do not concentrate on themes or a particular thread of evolution, but on some specific details about each text. 
The second chapter, for instance, stems from a letter James wrote to the editor of the Atlantic Monthly, William Dean Howells, anticipating the plot of The Europeans. This letter, instead of telling the actual story (24), gives account of what became a marginal part of it (25). This becomes a cue to revise unconventional words and details in the story to conclude that James plays "havoc with the foreground" (37) to create a sense of experience, which is not not only related to direct/sensual perception, therefore, it is conveyed through more than the conventional plot. Furthermore, the choice of such text could contribute to new interest in it in addition to speculation about Henry James's homosexuality being reflected in the novel or why it was left out of his New York Edition.

The third chapter brings queer theory to the forefront in order to address "The Pupil”, which seems predictable. What stands out as original, however, is that Zwinger does so by comparing the story to the action film The Last Boy Scout (1991), inviting us to reflect upon the paradoxical nature of the American concept of masculinity. Similarly, chapter six shockingly links Tarantino's Kill Bill (2003) with "The Jolly Corner” through Jacques Derrida's philosophy. Chapter four, on the other hand, is free of shocking comparisons and concentrates on "one of the great monuments of the novel in English” (60), namely The Golden Bowl, from the point of view of language. In this case, Zwinger finds childish puns and dirty jokes in almost every name that will strike readers who are not too familiar with James's writing process, succeeding in highlighting the importance of form in prose too.

Finally, instead of providing an orthodox conclusion chapter, Zwinger offers a collage of various authors on James, including herself. She analyses James's essay "Anthony Trollope" (1883) alongside "The Art of Fiction" (1884) and connects them back to the "web of experience" (120) she has spun throughout the book to conclude that "telling is not mere reporting" (129), as she has tried to demonstrate, not only with her analysis of James's career, but also with her own free use of such a rigid format as the academic.

In this regard, I must admit that Zwinger's eclectic and heterodox style is not for everyone. Even though I think that encompassing many theories in a monograph revolving about Henry James is positive, and limiting to a single approach we can fail to grasp it in its totality, the unsteady cohabitation of Victorian and Edwardian ideas with quotations from postmodern thinkers such as Kristeva, Deleuze and Genette that are sprinkled everywhere make this piece at times confusing. In other words, abrupt transitions from one section into the other and the lack of chronological order in the use of theory may occasionally hinder 
understanding. Furthermore, it is shocking that, there being endless specific literature on James, the author uses so little. Thus, I would not recommend this book to beginners. Rather, Zwinger's piece of criticism will result more enjoyable to those already acquainted with James's works and Jamesian criticism.

Nevertheless, in order to convey the idea that James's fiction is playful, Zwinger's book, in its oddness, is playful too. Humour, striking analogies, and the quasi-modernist style of Telling in Henry James make of its reading a memorable and thought provoking experience that will certainly make us look at James's spectre with different eyes.

Celia Cruz-Rus

Universidad de Málaga

celcruzrus@uma.es

\section{Acknowledgements}

The research of the author of the review is funded by the Spanish MECD (ref. FPU2013/01265), the group Hum-858 "Literaturas contemporáneas en el ámbito europeo" (Junta de Andalucía), and the thematic network "Victorian and Neo-Victorian Studies in Spain Network (VINS)” (ref. FFI2015-71025-REDT).

\section{Works Cited}

LODGE, D. (2006) 2007. The Year of Henry James: The Story of a Novel. London: Penguin. 